\title{
VIEWS ON THE STRUCTURAL-SEMANTIC AND FUNCTIONAL CLASSIFICATION OF SYMBOLS
}

\section{Akmaljon Uktamovich Abdullaev}

Lecturer Department Of Uzbek Language And Literature, Fergana State University, Uzbekistan

\section{ABSTRACT}

This article reflects the views of scholars from various fields of science on symbols and their classification, and the symbols used in the Uzbek language are divided into groups from a linguistic point of view.

KEYWORDS: - Symbol, structural-semantic, functional, extrolinguistic symbols, word-symbols, "formcontent relationship", image, metaphorical symbols, metonymic symbols, semantic element, aesthetic object

\section{INTRODUCTION}

The division and study of symbols into specific spiritual groups serves to reveal the essence of the methodological tools that are considered complex in science. As mentioned earlier, symbols are studied not only from a philological point of view, but also in such fields of science as philosophy, logic, psychology, linguoculturology, literature, cultural studies, semiotics. This phenomenon is interpreted in the context of these disciplines and is classified according to the characteristics of each field. Research shows that due to the diversity of views on symbols, so far no definite conclusion has been reached in the classification of this phenomenon.

\section{THE MAIN FINDINGS AND RESULTS}

While some researchers view symbols as a type of symbol, some scholars interpret them as an image or metaphor. In the emergence of these ideas, the connection between the more expressive and the expressed, the functions performed by the symbols, is taken into account.

For example, in cultural studies, a symbol is considered to be a special type of symbol that provides a direct spiritual connection with the being it represents. [2]

The author of the article "Symbol" A.G. Sheikin considers the category of symbols in several aspects. According to him, the symbol:

1. A symbol-like concept in artificially formed languages.

2. In the aesthetics and philosophy of art - a universal category, reflecting the specific 
CURRENT RESEARCH JOURNAL OF PHILOLOGICAL SCIENCES 2(6): 67-72,

May 2021 DOI: https://doi.org/10.37547/philological-crjps-02-06-14

ISSN 2767-3758

(C)2021 Master Journals

\section{Crossref do) 8 Google}

Accepted25thJune, 2021 \& Published 30thJune, 2021

features of the figurative understanding of life through art, a semantic element of the work of art.

3. In socio-cultural sciences, it is a material or ideological cultural object that acts as a symbol in the communicative or translational process, and is a traditional copy (analogue) of the meaning of another object $[12,199]$.

A symbol is a type of idea expressed figuratively in the field of art or, conversely, an idea expressed through an image $[11,3]$.

In sociology, a symbol is any gesture, artifact, sign, or concept that represents something, signifies a meaning[1].

It can be seen that there are two different views on the essence of the symbol in the philological literature. Some scholars (A.A.Potebnya, A.Belyy, V.V.Vinogradov, A.F.Losev) depicted the symbols, some (V.M.Zhirmunsky, B.S.Meyyaakh, N.K.Gay, V. P, Grigorev) attribute the symbol to migration [10]. According to VV Vinogradov, symbols are an aesthetically decorated, artistically limited, emotionally-figurative meaning in the composition of a work of art, and the meaning is a unit of speech conditionally connected with an aesthetic object [3, 240-249]. V.M. Zhirmunsky notes symbols as a special type of metaphor [5].

According to the Internet electronic resource "Encyclopedia Around the World" a symbol is an image, thing or event that conditionally represents an idea, concept or image. It is such an image that it can embody content and relationships, and with this feature it is close to the concept of character, but these two concepts have different aspects "[14].

From the above, it can be seen that the diversity of opinions about symbols also leads to a number of difficulties in classifying this phenomenon. Nevertheless, we found it necessary to focus on the classifications made by some researchers.

Initially, symbols can be divided into simple and complex symbols according to their structure. In this case, as simple symbols it is necessary to specify the symbols consisting of one element or a single word (concept). For example, the composition of apple, sun, morning, and similar symbols consists of a single object, represented by a single word. Complex symbols, on the other hand, are the result of a combination of two or more things. For example, a red rose (a combination of the terms "red" and "rose"), a national flag, and so on.

The symbols have been classified differently by different researchers based on the main and specific features of this phenomenon. In particular, the Russian scientist A. Losev in his work "The problem of symbols and realistic art", taking into account the functional nature of the symbols, divides them into the following types:

1. Scientific symbols. Special symbols related to this type of science, such as mathematics, geometry, are included.

2. Philosophical symbols are represented as philosophical concepts and categories.

3. Artistic symbols. The author notes that the presence of elements of symbols in artistic images, in a sense, there is a similarity in their properties, and artistic images rise to the level of symbols.

4. Mythological symbols. Heroes and images mentioned in legends that have a symbolic meaning are included in this category. However, they need to be distinguished from religious symbols.

5. Religious symbols. These types of symbols include symbols that have entered culture through religious teachings, such as Buddhas, icons and images.

6. Symbols of nature, society and the whole world. It is noted that the deep perception and study of everything in nature, society and the world by man acquires specific 
CURRENT RESEARCH JOURNAL OF PHILOLOGICAL SCIENCES 2(6): 67-72,

May 2021 DOI: https://doi.org/10.37547/philological-crjps-02-06-14

ISSN 2767-3758

(C)2021 Master Journals

\section{Crossref doi) 81 Google}

Accepted25thJune, 2021 \& Published 30thJune, 2021

symbolic meanings. It is considered impossible to understand the essence of every object and event without symbolic thinking.

7. Symbols associated with the image of people. These are the symbols that occur in the process of expressing one's inner world, feelings through one's appearance. For example, redness, whitening of the face and other signs of excitement are noticeable. These characters have a unique symbolic meaning.

8. Symbols of ideology and motivation. This type includes slogans, appeals, projects, programs, decisions, posters and other similar tools, taking into account their aspects of expressing abstract concepts (meanings) and evaluating them as symbols from a logical point of view.

9. External technical symbols. This type is close to social symbols, which include actions, sounds, processes that are actively used in society and can express symbolic meaning. For example, a number of actions such as the conductor's hand movements, the siren of a fire truck, the movement of human body parts in greeting and other situations (shaking hands, taking off a hat), writing elements [8, 97-110].

E.V. Zmanovskaya in her book "Fundamentals of Applied Psychoanalysis" suggests a garden form of classification of symbols:

1. Figurative symbols (for example, images of nature or animals);

2. Graphic symbols (eg cross, star);

3. Mathematical symbols (numbers, actions);

4. Name-related symbols (names and titles);

5. Symbols representing color;

6. Behavioral symbols (gestures);
7. Symbols of value expressed in words (e.g., freedom, justice, homeland, etc.);

8. Personal symbols (heroes, images of gods, etc.) [6].

In addition to the above, scientists I.G.Pendikov and L.S.Rakitina divide symbols into a) anthropological, b) social and c) cultural groups and analyze the processes of symbolism under these names [9].

The Russian linguist E.V. Shelestyuk analyzes the English poetry of the XX century and divides the symbols used in it into two main groups - metaphorical and metonymic symbols, taking into account the microsemantic connection of meanings $[14,120]$. It focuses on the relationship between the expressive and the expressive, more specifically, the type of meaning transfer. For example, the rat as a metonymic symbol - a symbol of crisis, the tower in the woods - a symbol of Spain; as a metaphorical symbol the sea is recorded as a symbol of the evolution of life, the train as a symbol of time, the sacred Byzantine city as a symbol of paradise.

I.V. Guzenko analyzes the use of symbols of Christianity in the Russian language and divides such symbols into lexical-semantic groups on the basis of the principle of "from form to content" and "from content to form" [4]. In this classification, the form (name) of the symbolic means is primary. For example, roses - belong to the group of symbols associated with the name of the plant. Based on the principle of "from content to form", the meaning and content expressed are taken as a basis. For example, it will be possible to include black, night, devil, and others in the group of those who represent evil.

In this study, I.V. Guzenko classifies the existing symbols of Christianity in the Russian language on the basis of the principle of "from form to content" and divides them into the following 6 
CURRENT RESEARCH JOURNAL OF PHILOLOGICAL SCIENCES 2(6): 67-72,

May 2021 DOI: https://doi.org/10.37547/philological-crjps-02-06-14

ISSN 2767-3758

(C)2021 Master Journals

\section{Crossref do) 8 Google}

Accepted25thJune, 2021 \& Published 30thJune, 2021

lexical-semantic groups:

a) symbols naming creatures (animals, birds, etc.);

b) symbols naming plants (trees, flowers, etc.);

c) symbols of religious origin (icons, images of gods);

d) symbols representing celebrities and creatures (Jesus, Mary, etc.);

e) symbols representing natural objects and phenomena (fog, rain, wind, snow, etc.);

f) names denoting the objects of worship and religious ceremonies (altar, church, candle, etc.) [4].

Russian linguist M. Kostomarov in his research states that Russian folk symbols are derived on 3 bases and divides them into 3 groups:

1. Symbols that have their basis in nature and are clearly understandable.

2. Symbols based on objects that have been used historically in ancestral life.

3. Symbols based on ancient myths, fairy tales and legends $[7,58]$.

From the above, it can be seen that the issue of evaluating and classifying symbols as a separate phenomenon has not yet been fully resolved. No classification can fully reflect the essence and characteristics of a symbol. In fact, symbols can be taken as units that can be imagined and evoked by the human senses (sight, hearing, sensation, smell) or perception, regardless of their form.

Therefore, in our work we have tried to study the symbolic units in the Uzbek language by dividing them into a number of semantic groups. In this classification, we worked on the principle of "from form to content".

First of all, it is expedient to divide the symbols into two main groups: original symbols and conditional symbols. In this case, it is possible to include conditional symbols, that is, symbols that belong to the fields of science: mathematics, chemistry, physics, information technology, etc. and are conditionally accepted, not expressing concepts related to emotion in man, but only performing technical functions. For example,

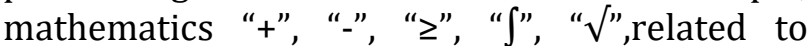
chemistry "Fe", "Na", related to physics " $\Omega$ ", “ $\Psi$ ", " $\varphi$ " etc. are conditionally accepted symbols, the function, content and essence of which are radically different from the original symbols.

Original symbols, on the other hand, include units that, through their content, have a broader but abstract meaning and affect human emotion. For example, the morning is a symbol of good intentions, new hope, purification.

The original symbols can be divided into the following semantic groups:

1. Extrolinguistic symbols. Symbols used in the form of images, emblems, icons, statues and other forms of communication. These include the image of a cross, a five-pointed or three-pointed star, an image of a snake poisoning a vessel, a sword and shield, state emblems, a crescent moon, a statue of Femida, and more. Some gestures, such as the movement of human body parts (hands, head, eyes, face, etc.), are also symbolic. In these tools, mainly the image is the leader.

2. Word-symbols. This group can include types of symbols, mainly expressed in words. The main part of the symbols belongs to this group, they consist of words with a definite (concrete) meaning and serve to express abstract concepts. Symbols of this type can be grouped in the following order:

1. Allegorical symbols. Symbols represented by the names of creatures. For example, a lion is a symbol of courage, a fox is a cunning, humo is a 
CURRENT RESEARCH JOURNAL OF PHILOLOGICAL SCIENCES 2(6): 67-72,

May 2021 DOI: https://doi.org/10.37547/philological-crjps-02-06-14

ISSN 2767-3758

(C)2021 Master Journals

Crossref dof 81 Google

Accepted25thJune, 2021 \& Published 30thJune, 2021

symbol of happiness, and a vulture is a symbol of youth..

2. Phytonymic symbols. Symbols represented by plant names and related concepts. Chuchmoma symbolizes the beginning of life, tulip symbolizes humility, apple symbolizes love, maple symbolizes energy, longevity.

3. Symbols denoting the names of objects. For example, the ring is a symbol of marriage, family, mountain - height, water - purity, a symbol of life.

4. Color symbols. Symbols expressed through colors that are actively used in social life. For example, red is a symbol of love, yellow is a symbol of hijrah, separation, blue is a symbol of mourning, and sky blue is a symbol of virginity.

5. Number - symbols. There are quantitative numbers in our language, such as "three", "seven", "forty".

6. Symbols represented by natural phenomena and celestial bodies. For example, wind, rain, snow, fog, Sun, Moon, and so on.

7. Words and symbols meaning time. Parts of the day are symbols that represent names associated with the seasons. For example, morning, night, spring, autumn, and so on.

8. Symbols represented by person and place names. This group includes symbols represented by historical or celebrity figures, the names of a particular region. For example, Farhod, Majnun, Karbala steppe, desert, valley, etc. are widely used in symbolizing concepts with human emotion.

\section{Conclusion}

In addition to the above, the linguistic units that represent a symbol can also be classified according to their syntactic functions in a sentence, according to their expression and structure within word groups. All this helps to identify the specific features of the symbols, their different aspects from other symbols.

\section{REFERENCES}

1. Abercrombie N.A., Turner B.S., Hill S. Sociological Dictionary. ... Moscow: 2000. -p. 286.

2. Avdeev V.I., Arapov A.V., Vystavkin A.V. and other Encyclopedic Dictionary of Cultural Studies, Moscow: Center, 1997. -p. 346.

3. Vinogradov V.V. Selected Works. On the language of fiction. Moscow: 1980. -pp. 240249

4. Guzenko I.V. Christian symbolism in Russian: verbalization, functioning, evolution. Abstract of the dissertation for the degree of candidate of philological sciences. Moscow: 2009, p. 237.

5. Zhirmunsky V.M. Literary theory. Poetics. Stylistics. "Science" Leningrad branch, Leningrad. 1977, -p. 408.

6. Zmanovskaya E.V. Fundamentals of Applied Psychoanalysis, Ed. "Speech”, 2005

7. Kostomarov M. Slavic mythology. K. "Libid", 1994. p. 384 - p. 58

8. Losev A.F. The symbol problem and realistic art. - 2nd ed., Rev. Moscow: Art, 1995. -320s. -p. 97-110.

9. Pendikov I.G., Rakitina L.S. Archetype and symbol in advertising. Moscow: "UNITI", 2012. -p. 304.

10. Popa N. D. "Semantic and stylistic originality of the color symbol in Soviet prose" of the dissertation for the degree of candidate of philological sciences, St. Petersburg, 1991

11. Roshal V.M. Encyclopedia of symbols. Moscow: AST; SPb .: Sova, 2008. -p. 94.

12. Sheikin A.G. Symbol. Culturology. XX century. Vocabulary. SPb: - University book, 1997. - p. 
CURRENT RESEARCH JOURNAL OF PHILOLOGICAL SCIENCES 2(6): 67-72,

May 2021 DOI: https://doi.org/10.37547/philological-crjps-02-06-14

ISSN 2767-3758

(C)2021 Master Journals

Crossref do: 81 Google

Accepted25thJune, 2021 \& Published 30thJune, 2021

404.

13. Shelestyuk E.V. The semantics of the artistic image and symbol (based on the material of the English-language poetry of the twentieth century). Dissertation for the degree of candidate of philological sciences. Moscow: 1998, -p. 120.

14. Electronic encyclopedia. "Encyclopedia Around the "World" https://www.krugosvet.ru/.

15. Abdupattoev M. T. Unusual Connections As Forming Literary Text //The American Journal of Social Science and Education Innovations. - 2021. - T. 3. - №. 02. - C. 177182.

16. Karimov, U., \& Abdurakhmon, A. (2017). INNOVATIVE INFORMATION TECHNOLOGY IN EDUCATION. Форум молодых ученых, (5), 9-12.

17. Karimov, U., \& Kasimov, I. (2018). THE IMPORTANCE OF MODERN INFORMATION TECHNOLOGIES IN DEVELOPMENT OF DISTANCE EDUCATION. In Перспективные информационные технологии (ПИТ 2018) (pp. 1186-1187).

18. Kuzibaevna, O. G. (2020). TECHNOLOGIES OF DEVELOPING THE ECOLOGICAL CULTURE OF STUDENTS IN THE PROCESS OF LEARNING A FOREIGN LANGUAGES IN HIGHER EDUCATIONAL INSTITUTIONS. Solid State Technology, 63(1s), 1816-1825.

19. Abdupattoev, M.(2021). COMPOSITIONAL STRUCTURE OF MICROMATES. Конференции, 1(2). https://doi.org/10.47100/.v1i2.153.

20. Abdurashidovich K. A. Motivation and National Character of Foolishness in Uzbek Literature //ANGLISTICUM. Journal of the Association-Institute for English Language and American Studies. - 2018. - T. 7. - №. 4.
- C. 47-51.

21. Qayumov A. CREATING OF A NATIONAL CHARACTER THROUGH MEANS OF LITERATURE //Theoretical \& Applied Science. - 2018. - №. 1. - C. 235-240. 